\title{
Returns to Education in South Africa: Evidence from the Machibisa Township
}

\author{
David Fryer \\ Department of Economics and Economic History \\ Rhodes University \\ Grahamstown, South Africa \\ d.fryer@ru.ac.za
}

\section{Désiré Vencatachellum}

IEA, HEC Montreal, Universite de Montreal

3000 Cote-Ste-Catherine

Montreal (Qu ebec) Canada H3T 2A7

dv@hec.ca 


\section{Abstract}

We develop a model where blacks in the private sector earn no returns to education if there are relatively too few educated blacks. Using a sample of black females in the late apartheid Kwa Zulu to control for labour market specific effects, we find that more than a fifth of labour market participants are self-employed. There are no returns to primary education and positive returns for the first two years of secondary education. Further education allows females to find employment in the government sector where they earn a wage premium. Only secondary education is a predictor of earnings status, and new migrants are most likely to be unemployed. Our analysis therefore contributes to challenging the consensus on high returns to primary education in developing countries.

JEL Classification: D45, L10

Keywords: South Africa, Apartheid, Returns to education, Skill-biased technologies

The policy of mission education to train young black girls in domestic skills, such as sewing and cooking, had a further impact. It is against this backdrop that women's dominance in sewing, catering, and small commercial businesses focussed on these items must be understood. [Friedman and Hambridge (1991, p. 170)]

\section{Acknowledgements}

We are indebted to Professor Norman Bromberger for providing us with the data. We thank Tom Hertz, seminar participants at the 2002 DPRU/FES conference, Marie Allard, Benoit Dostie, Pierre-Thomas Leger, Pascal St-Amour and Bruno Versaevel for helpful comments. Part of this research was completed while the second author was Hobart Houghton research fellow at Rhodes University. Vencatachellum ${ }^{1}$ thanks the FCAR for funding.

Development Policy Research Unit Tel: +27 216505705 Fax: +27216505711
Information about our Working Papers and other published titles are available on our website at: http://www.commerce.uct.ac.za/dpru/

\footnotetext{
${ }^{1}$ Vencatachellum is a research fellow at CIRANO. Corresponding author: D. Vencatachellum, Fax: (514) 340-6469
} 


\section{Table of Contents}

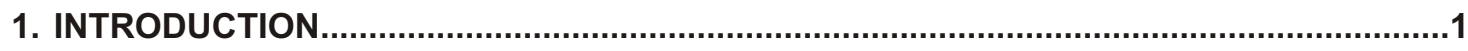

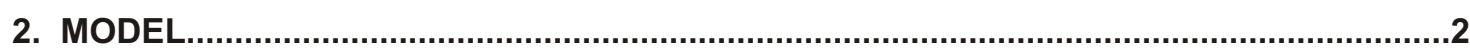

3. APARTHEID AND THE MACHIBISA TOWNSHIP......................................................4

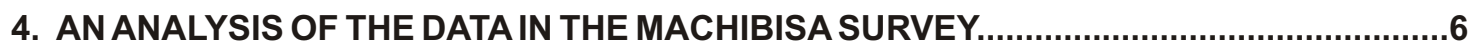

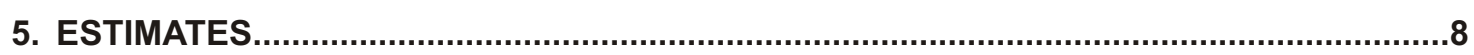

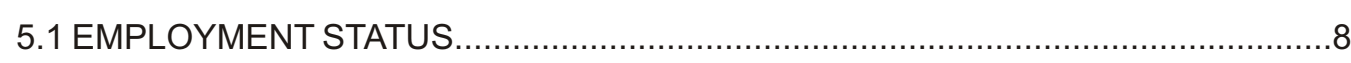

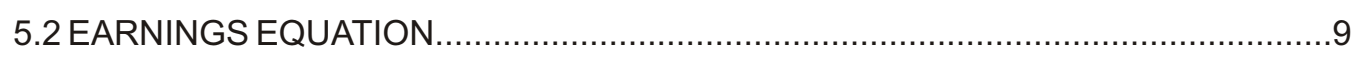

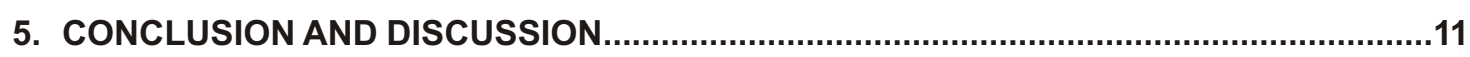

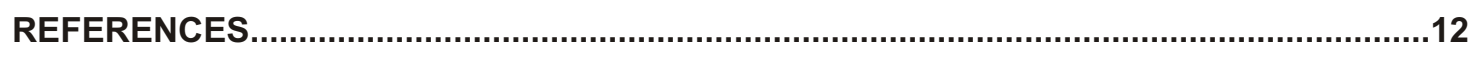

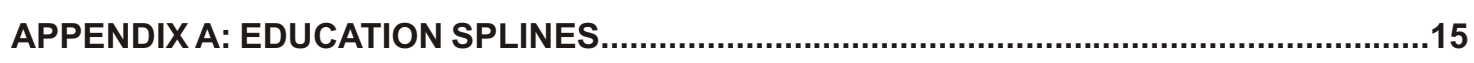

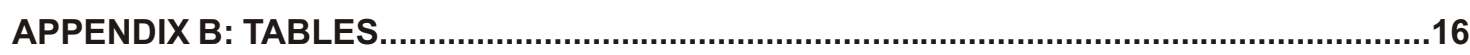

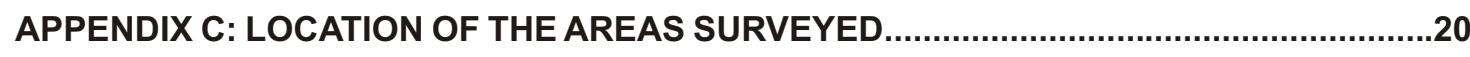




\section{Introduction}

The economic development literature argues that there are high returns to schooling in developing countries. Reviewing the literature on returns to investment in education, Psacharopoulos and Patrinos (2002, Table 4, p. 14) report an average rate of return to schooling of 9.9 and 11.7 per cent for Asia and sub-saharan Africa respectively. However, work by Behrman and Deolalikar (1993) in Indonesia, and studies in South Africa (Pillay 1992, Schultz and Mwabu 1998), find low returns to primary education. Furthermore, these returns in South Africa virtually disappear once community fixed-effects are accounted for (Moll 1998, Butcher and Rouse 2001). Moll (1996) explains this by the poor quality of schooling and the adverse role played by trade unions and Industrial Councils.

While the returns to education (net of transaction costs) should not differ across regions when labour is mobile, it may be strongly influenced by regional characteristics such as the historical restrictions on the mobility of labour in South Africa (e.g. the pass laws). However, to our knowledge, most of the analysis on wage determinants in South Africa treat labour market characteristics as a fixed effect, yet do not allow the returns to education to vary across regions. This occurs because national surveys contain too few observations of community to include both a community dummy and its interaction with the number of years of education as explanatory variables in wage equations. ${ }^{2}$ Heckman, Layne-Farrar and Todd (1996) show that in the U.S., regional labour markets affect the economic returns of unskilled workers, and that returns to education should be non linear. This omission in the studies of the rate of returns to education in South Africa may bias the estimates.

In this paper, we investigate the possibility of an education threshold for the employment of black women in the Machibisa township of Kwa Zulu and estimate the returns to schooling for this population. This question is of interest because:

(i) Using data from one region allows us to account for labour market specific factors,

(ii) Females, as in other developing countries, are the most affected by poverty (Bhorat Leibbrandt, Maziya, van der Berg and Woolard 2001), and

(iii) Alarge share of the black population live in townships.

While in national data sets (e.g. the 1993 South Africa Project for Statistics on Living Standard and Development (PSLSD) less than one per cent of females are self-employed, this is not the case for Machibisa females where slightly more that one in five is self-employed. Furthermore, most Machibisa women hold jobs which use domestic skills such as domestic workers or self-employed hawkers. Our analysis is also relevant for other developing countries as women in those countries share some of the same characteristics as those in our sample.

We first set up a simple model where black workers in the private sector earn no return to education. If the average human capital externalities of blacks are too low, then a white worker's wage will be greater under a technology which uses only skilled whites. Our estimates suggest that the returns to education are:

(i) Nil for those with only primary education,

(ii) Positive for the first two years of secondary education, and

(iii) Highest for those in the government sector.

${ }^{2}$ The same critique may apply to much of the returns to education literature. For example Trostel, Walker and Wolley (2002) do not control for sectoral and cluster specific effects. These omissions may bias the estimates of the returns to education upwards as shown in Michaud and Vencatachellum (2003). 
Furthermore, only secondary education is found to be a significant predictor of employment status and we also find that new migrants to Machibisa are most likely to be unemployed. These results may arise because of apartheid policies, skill-biased technologies used in nearby Pietermaritzburg as well as the low quality of effective education. Our results confirm Wilson and Ramphele's (1989, p. 148) claim that age, gender and previous experience are more relevant than education for most blacks. In a broader perspective, our analysis contributes to challenging the consensus on high returns to primary education in developing countries.

The remainder of the paper is organised as follows: We set up the model in section 2. Section 3 describes relevant apartheid policies and some characteristics of the area surveyed. We analyse the data in section 4 , and discuss the estimates of the selection and wage equations in section 5 . Finally, section 6 concludes. All tables are in the appendix.

\section{Model}

Consider an economy populated by blacks and whites. ${ }^{3}$ Assume that agents derive utility only from consumption and are endowed with human capital which they sell on the labour market. We further assume that the average level of human capital of whites (hw) exceeds that of blacks (hb) in order to reflect the well known stylised fact for South Africa (Knight and McGrath 1977, Michaud and Vencatachellum 2003). In fact, in the 1993 PSLSD more than 72 per cent of the white labour market participants had completed secondary school, while only 16 per cent of blacks had done so (Michaud and Vencatachellum 2003, Table 3). For simplicity, we also assume that all whites are endowed with sufficient human capital to work as skilled workers, while a positive measure of blacks have sufficient human capital to work at most in semi-skilled occupations but not as skilled workers.

We consider a two-sector economy producing a numeraire non-storable good. In the informal sector, firms are perfectly competitive and use labour at wage rate $w_{u}$ irrespective of the worker's human capital. In the formal sector, firms operate in perfectly competitive labour and goods markets, but have access to two constant returns to scale technologies. The first technology uses only skilled white workers and, as in Lucas (1988), the average level human capital (in this case of whites only) has a positive externality.

$$
\mathrm{Y}_{\mathrm{w}}=\alpha \mathrm{h}_{\mathrm{w}} \mathrm{x}_{\mathrm{w}}
$$

where $a$ is a positive scale factor as in Azariadis and Drazen (1990), and $x_{w}$ is the amount of white skilled human capital. 
The second technology, also with human capital externalities, uses a weighted sum of skilled (white) and semi-skilled (black) labour. Following Galor and Moav (2000) we assume the following production function:

$$
\mathrm{Y}_{\mathrm{b}}=\mathrm{h}_{\mathrm{w}}^{\gamma} \mathrm{h}_{\mathrm{b}}^{1-\gamma}\left(\mathrm{x}_{\mathrm{w}}+\mu \mathrm{x}_{\mathrm{b}}\right)
$$

where $\mu$ captures the degree of substitution between skilled whites and semi-skilled blacks, $x_{b}$ denotes the amount of semi-skilled black human capital and $\gamma \in[0,1]$. If $\gamma=1$ then blacks do not generate any externalities at the aggregate level. Note that (2) simplifies to (1) if the following three conditions hold:

(i) The scaling factor a equals 1 ,

(ii) White workers and black semi-skilled workers are perfect substitutes $(\mu=1)$, and

(iii) Blacks and whites have the same average human capital $\left(h_{w}=h_{b}\right)$.

Given that firms are perfectly competitive, they earn zero profits under either one of the two technologies. We assume that the technology choice is the outcome of a political process as explained below. Let $\lambda$ denote the labour market policy adopted by the government. If $\lambda=0$, the government does not discriminate against semi-skilled blacks, while if $\lambda=1$, they are barred from the formal sector. Hence, aggregate production in the formal sector equals $Y_{w}$ if $\lambda=1$, and $Y_{b}$ otherwise. Given that utility is defined only over consumption, and that the numeraire good is nonstorable, an apartheid government chooses the discrimination level which maximises a representative white's wages because blacks cannot vote. In equilibrium, human capital is paid its marginal product and all markets clear. Consequently, making use of (1) and (2), the price of one unit of white human capital equals:

$$
\omega_{\mathrm{w}}=\lambda \alpha \mathrm{h}_{\mathrm{w}}+(1-\lambda) \mathrm{h}_{\mathrm{w}}^{\gamma} \mathrm{h}_{\mathrm{b}}^{1-\gamma}
$$

and the price of one unit of human capital of semi-skilled black workers equals:

$$
\omega_{\mathrm{b}}=\lambda \omega_{\mathrm{u}}+(1-\lambda) \mu \mathrm{h}_{\mathrm{w}}^{\gamma} \mathrm{h}_{\mathrm{b}}^{1-\gamma}
$$

From (4), educated blacks could earn returns from human capital even under apartheid provided they could work as semi-skilled workers $(\lambda=0)$. If they are discriminated against $(\lambda=1)$, then from (4) all blacks work as unskilled workers and earn a wage $w_{\mathrm{u}}$ : In this case their human capital is not rewarded. If there is no discrimination and qualified blacks can work as semi-skilled workers, they earn lower wages than skilled whites as long as these two types of labour are not perfect substitutes $(\mu<1)$. In this model, skilled whites and semi-skilled blacks earn the same wages if they are perfect substitutes $(\mu=1)$. Finally, note that the white wage premium, given by (3) minus (4), is increasing in the average level of human capital of whites for $\mu<1$. To the extent that whites are skilled workers, and blacks semi-skilled, this difference is also equal to the skilled-wage premium. 
From (3), it is optimal for an apartheid government to discriminate against black semi-skilled workers $(\lambda=1)$ if

$$
\mathrm{h}_{\mathrm{b}}<\alpha^{\frac{1}{1-\gamma}} \mathrm{h}_{\mathrm{w}}
$$

Hence, when the average level of human capital of blacks is smaller than a threshold, then black workers enjoy no returns to human capital in the private sector. This discrimination arises because the apartheid government was maximising whites' wages because of the political process. Note however that this is a myopic decision whereby, from a pure efficiency point of view, it would have been optimal to increase the human capital of blacks sufficiently for whites' wages to exceed those they would obtain only under the technology which uses whites exclusively. A variant of our analysis is an insider- outsider model where the political process takes place inside a firm or industry. In order to maximise utility of insiders, a firm would implement the discriminatory policy, i.e. choose a skill-biased technology.

If human capital is acquired through schooling, as is the case in real life, then there are no returns to education for blacks when (5) holds. ${ }^{4}$ Note that:

(i) A similar condition to (5) is obtained if we use more general production functions with human capital externalities, and,

(ii) Condition (5) may be violated even if the average human capital of blacks is smaller that that of whites $\left(h_{b}<h_{w}\right)$ provided that the scaling factor a is not too high. We now take our model to the data to investigate whether educated blacks who work in the private sector earn returns to education.

\section{Apartheid and the Machibisa Township}

In South Africa, the apartheid regime relied heavily on policies which controlled the mobility of blacks. The 1950 Group Areas Act, which segmented communities, and the Population Registration Act, which classified people according to their race, were the cornerstones of legislative apartheid. The mobility of blacks was regulated through a pass system and limited access to the housing market. According to the 1970 Bantu Homelands Citizenship Act, every black was a citizen of one of 10 Bantustans or homelands. ${ }^{5}$ The Housing Regulations for nonBantustan townships stipulated that all township residents had to be listed on a lodger's permit failing which they would not obtain ID documents from the Department of Home Affairs. Local authorities could remove the "redundant, idle, and unsuitable" from urban areas.

Despite these restrictions, African urbanisation proceeded rapidly after the late 1960s (Simkins 1983). The pressures towards urbanisation arose because of the push from high unemployment in the homelands (Wilson and Ramphele 1989, p. 93), and the pull of the modern urban sector. Many black workers (mostly males) lived in single-sex hostels near their workplace, in commuting communities on homeland borders, or in townships outside white urban areas (Percival and Homer-Dixon 1995). Most township residents were employed in industries, mines or as domestic labourers. With increased migration from the homelands, large illegal populations settled in squatter camps, in backyard shacks

\footnotetext{
${ }^{4}$ It would be of interest to investigate if (5) is robust in a general equilibrium framework as in Dessy and Vencatachellum (2003). This is not pursued here because we focus on an empirical analysis and establish a necessary condition for the absence of returns to education for blacks in apartheid South Africa.

${ }^{5}$ These 10 homelands, with the four independent ones enumerated first, were: Bophutatswana, Ciskei, Transkei, Venda; Gazankulu, Kangwane, Kwa Zulu, Kwa Ndebele, Lebowa and Qwaqwa.
} 
of formal townships, and many women settled illegally in male-only hostels.

While employed black males were accommodated in urban areas, women were regarded as "surplus appendages" who belonged in rural areas (Friedman and Hambridge 1991, p. 161). Female migrants to urban areas were confronted with an acute housing problem. Friedman and Hambridge (1991, p. 169) refer to instances where women were not allowed to live in formal townships and were forced into shack settlements. As a result, apartheid led to a high (low) male/female ratio in urban (rural) areas, and severe racial inequalities, with whites owning 87 percent of the land (Percival and Homer-Dixon 1995).

Our data is for the Machibisa Township in 1990. According to Simkins (1983) Machibisa was in Kwa Zulu, and lies about five kilometers west of Pietermaritzburg (PMB) (see the map in Appendix C). Kwa Zulu was poorer and less productive than Natal with lower agricultural yields and cattle raising performances (Bromberger and Antonie 1993, p. 421- 422). As in other homelands, the wealth differential with the white urban areas (Natal in this case) prompted Kwa Zulu females to migrate to informal urban satellite settlements to find work as domestics or in service occupations (Nattrass and May 1986, p. 591). Around PMB there are 3 main townships: Vulindlela, Imbali and Edendale. Machibisa is on the eastern (town) side of Edendale.

However, the particularities of land tenancy, and housing controls, made it difficult for females to move to urban areas. For instance, only males could own land in Vulindlela, while Imbali was a formal township where the state rented houses exclusively to employed males. Edendale, including Machibisa, was the only area where blacks had freehold land tenure throughout the apartheid period and where there was a free rental market. Thus Edendale became a port-of-entry for women into the PMB job market. Machibisa, in particular, fits this picture well, because it is located on the "town" side of Edendale which makes it a natural base for commuting and for informal businesses.

PMB is the capital of Kwa Zulu-Natal. It is part of the Pinetown-Pietermaritzburg-Durban urban hub with close to five million inhabitants, and has a large industrial base. The 1991 manufacturing census finds 27,000 manufacturing jobs in PMB, of which 13,498 were held by blacks. According to this census, most blacks work in the food sector. Although there is evidence of an important footwear industry, such a category does not exist in the census. These workers may be among the 4,491 in the "other" category. While there seems to be a relatively high demand for skilled workers in PMB, black female migrants are mostly unskilled.

The above situation may reflect a trend of increased demand for skilled labour and a fall in demand for unskilled workers in South Africa (Bell and Cattaneo 1997). Although influx control and residential segregation were no longer on the statute books by 1990 , their effects persisted including the effects of other legislation that had restricted the mobility of blacks. For instance, the Housing Regulations for non-Bantustan townships and laws against squatting and slums had a lasting effect on the residential mobility of blacks (Unterhalter 1987, p. 41). In spite of the many changes which took place in the late 1980s, the Machibisa labour market provides a coherent and representative picture for blacks elsewhere in South Africa (May and Rankin 1990). It is against this background that one should view the Machibisa data described next. 


\section{An Analysis of the Data in the Machibisa Survey}

A random sample of 20 percent of Machibisa households was surveyed between November 1989 and February 1990. The sample consists of 331 households and 1,310 individuals. To construct the sample of female labour market participants, we start with the 522 females who are older than 14. From this we subtract the sick (12), retired (21), scholars (44), housewives (48) as well as those who report not participating in the labour force without specifying a reason, leaving us with 385 labour market participants. The sample descriptive statistics are reported in Table 1. We now discuss the variables used in the participation and wage earning equations.

Unemployment: The estimated unemployment rate of black females in Machibisa of 39 percent is lower than that of the 1996 census or the 1993 PSLSD. This difference arises because selfemployed females may be classified in other occupational categories, or they may report being unemployed. For example, only 0.3 percent of female wage-earners are self-employed in the 1993 PSLSD. However, self-employment is the most important category in Machibisa accounting for 35 per cent of all jobs. If we assumed that all self-employed were in fact unemployed, then the Machibisa unemployment rate would increase to 58 percent, leaving us with the exact number for Kwa Zulu-Natal in the PSLSD. Hence, our sample provides evidence that national data sets may overestimate the unemployment rate because they miscode the self-employed.

Selection: Only 25 of the 150 unemployed females received job offers in the months prior to the survey. This provides some evidence that the Machibisa labour market is, to a large extent, a buyer's market. However, it is true that some unemployed turned down job offers. The jobs which were declined are, in order of importance: domestic work, manual labour, "shouting at the doors of Indian shops", and sewing shoes. Among the 25 who did receive offers, four reported not wanting the job because the wage offered was too low, while the rest were put off by the nature of the work or the conditions offered. This indicates that wage earners may not be representative of the labour market as a whole. In order to avoid potent bias in our estimates, we correct for sample selection when estimating the wage equation.

Age and migration: The average labour market participant in our sample is 34 years old. Those who are employed average 36 years of age, while the unemployed average 30 years of age. This age difference may reflect the difficulty which younger and inexperienced women face in finding employment. Moreover, it may reflect young females migrating to Machibisa because of the poor labour market conditions in the rural areas. Almost 30 per cent of Machibisa women of 25 to 55 years of age had migrated into the area during the five years prior to the survey. The high migration is in line with Cross, Bekker and Clark (1994) who report that Kwa Zulu experienced high levels of rural migration to urban areas. We expect new migrants in Machibisa to find employment less easily because they have few labour market contacts.

Household size: An average household in our sample is composed of 5.7 individuals, with 40 percent of household members being younger than 15 . Young children may require the attention of some care-giver, who in most cases is the mother, and may hinder her labour market participation. The number of family members in the household may also matter, especially for self-employed individuals. 
For instance, fruits and vegetables sellers may benefit from household members who can help her grow, collect, and transport the vegetables to the market place.

Marital status: As mentioned by Siphambe and Thokweng-Bawena (2001), being married may mean that an employer is more willing to invest in the human capital of the woman by giving her more training. Siphambe and Thokweng-Bawena (2001) are interested by the formal sector in Botswana where there are high returns to human capital and employers have an incentive to provide on-the-job training to their employees. Hence, ceteris paribus, a married woman is less mobile and has a smaller probability of leaving her job.

Wages: The average Machibisa female earns 82 rands per week which, however, hides severe disparities: 46 percent earn less than 50 rands, and 5 percent earn more than 200 rands per week. These low wages mirror the jobs that females have access to. Moreover the wage variance is quite high for the self-employed (see Table 1). For example, a mud block maker earns 7 rands 50 cents per week, while a traditional doctor (sangoma) reports weekly earnings of 380 rands. Such details are not available in the national surveys and provide an interesting insight into a township's labour market. It is also important to note that self-employment is the most common occupation among the uneducated. This may indicate that those who do not possess the skills to be wage earners are constrained to doing odd jobs or to being hawkers.

Occupation: Panel B in Table 1 reports the distribution of occupations. The unprotected sector is composed of those who work mostly under short term contracts and with little chance of being unionised. As for the protected sector, it is composed of tenured semi-skilled and unskilled labourers (Jagannathan 1987, p. 90). ${ }^{6}$ An interesting finding is the importance of self-employed females ranging from food street sellers to micro producers sewing clothes or brewing liquor at home. Indeed, Hart (1991, p. 78) notes that beer brewing is part of women's traditional role and that "A woman must be in a position to entertain her husband and his guests with beer". The magnitude of self-employment is in line with Liedholm and Mead (1998, p. 12), who document the importance of one-person micro-enterprises in urban areas of southern and eastern Africa, and (Rogerson 1996) who finds an expansion of informal retail businesses and hawker operations in South Africa.

Domestic workers constitute the most important occupation and earn the lowest wage. More than 50 per cent of domestic workers have completed primary school which may indicate that they work as domestics as a result of a lack of other opportunities. On the other hand, all those in the clerical sector have at least completed primary education, while more than 75 percent graduated from secondary school. Furthermore, clerical sector workers earn the highest wages. The occupational distribution in Machibisa is typical for blacks in South Africa from the mid-1980s (Nattrass and May 1986, p. 591), and is a consequence of the South African training institutions and constraints (Friedman and Hambridge 1991, p. 179).

Education: While the average labour market participant has completed primary school, 11 percent have never attended school, and less than 10 percent have completed their secondary education. The average number of years of education for Machibisa females does not differ from the 6.7 average years of education for the Kwa Zulu-Natal province in the 1993 PSLSD. Schooling may have non-linear 
effects on earnings if there are educational thresholds in skills acquisition. Indeed, May and Rankin (1990, p. 588) state that there is no retention of literacy for less than 5 years of education. Moreover, Wilson and Ramphele (1989, p.148) note that there are important returns to breaking the standard 8 (Grade 10) barrier which allows one to find white-collar jobs, while the prospect is bleak for those who fail.

To investigate if the returns to education are constant within an education cycle we modify Moll's (1993) specifications of the education variable following Wilson and Ramphele's (1989) conjecture. The first four years of primary education constitute a lower-primary spline, while the last three years form the upper primary spline. Similarly, we specify a spline for the first two years of secondary education, and another spline for upper secondary and tertiary education. We merge upper secondary and tertiary education because there are only 3 females with tertiary education. If the returns to education are constant within a cycle, then the coefficients should not differ between the lower and upper cycles. Appendix A formalises these splines.

Edendale: The Machibisa data suggests that there are few job opportunities for women, many of whom earn a living from the informal sector (Gerson 1986, Wilson and Ramphele 1989). However, given that PMB has a greater industrial base than Edendale, those who work in PMB should earn a wage premium relative to those in Edendale. We can now investigate the explanatory power of the variables discussed above in explaining a female labour market participant's employment status and earnings.

\section{Estimates}

\subsection{Employment Status}

As is standard in the labour literature, we assume that a labour market participant accepts a wageearning position, or becomes self-employed, if her expected utility from being employed is greater than her expected utility from the alternative (Heckman, Lochner and Todd 2001). However, we do not observe a labour market participant's net expected benefits but only her employment status. We specify a probit model where the dependent variable equals 1 if the labour market participant earns positive earnings, and 0 otherwise, and with the explanatory variables described in the previous section. The results are reported in Table 2.

The model fits the data quite well, with 68 percent correct predictions. However, some of the explanatory variables do not have the expected theoretical sign. The number of years of education should in theory increase the likelihood of finding employment. However, our estimates in Table 2 show that only secondary education is significant in explaining a labour market participant's status. This finding confirms Wilson and Ramphele's (1989) conjecture that primary education is not a determinant of employment for blacks. This result may arise because the labour market for unskilled black females is a buyer's market which finds support in the few unemployed who received job offers during the months prior to the survey. Hence, many Machibisa females are constrained into accepting mostly unskilled positions. 
The implications (of this result) are that, ceteris paribus, increasing black females' education will not increase their likelihood of being employed unless they graduate from primary school and acquire some secondary education. Otherwise, the chance to lift those who are trapped in long term poverty, as documented by Carter and May (2001), is small. The likelihood of finding employment may increase even more if labour demand increases with the share of educated females. This may be the case if:

(i) More skilled workers prompt firms to adopt skill-biased technologies, which in turn increase the demand for skilled workers (Acemoglu 1998, Acemoglu 2002), and

(ii) Employers do not discriminate against black females.

We also control for a labour market participant's marital status, household size and migration. The married dummy is not significant as a determinant of employment for Machibisa females. This result may arise because females in Machibisa are mostly in unskilled occupations (domestics or self-employed hawkers) which are not human capital intensive. ${ }^{7}$ The effect of household size is not significant. Finally, ceteris paribus, our conjecture that it is more difficult for new migrants to find employment is confirmed by our estimates.

\subsection{Earnings Equation}

We next estimate the Mincerian earnings equation using Heckman's (1979) two-step procedure to correct for sample selection. The estimates are reported in Table 3. We also estimate the earnings equation without accounting for sample selection and report the results in Table 4. Drawing on similar results to Mwabu and Schultz (2000) and Michaud and Vencatachellum (2003) we find no qualitative difference between those two sets of estimates. This is consistent with the fact that the inverse of Mill's ratio is never statistically significant in Table 3 , which indicates that sample selection does not matter for female labour market participants in Machibisa. The remainder of this section focusses on the results reported in Table 3.

Given the small sample size, the specifications which include occupation dummies fit the data well with an adjusted R-square which varies between 0.37 and 0.38 . Five out of seven occupation dummies are statistically significant. It is of interest to note that, although no sangoma (traditional doctor) has completed secondary school, her earnings premium is close to that of someone who works in the clerical sector. It must however be noted that the skills required to be a sangoma are not acquired through schooling, but are learnt informally. Thus, to this extent, a sangoma may be considered as a skilled worker who earns an appropriate premium.

We find no returns to primary education irrespective of whether we use the restricted or unrestricted education splines. We do not reject the assumption that the returns to education at the lower and upper primary levels are the same and equal zero. This result is robust to the exclusion of occupation dummies in the earnings equation (model 2A). Our results are consistent with Soderbom and Teal (2001) who find no returns to primary education in Ghana. Given the critique that empirical studies using cross-sectional data overestimate the returns to education because of ability bias (Ashenfelter, Harmon and Oosterbeek 1999, Card1999), we can confidently state that our result provides evidence that there are no returns to primary education for females in Machibisa. 
This result therefore contributes to challenging the consensus on high returns to primary education in developing countries. We find positive returns at the lower secondary education and no returns at the upper secondary. This suggests that ceteris paribus women with upper secondary education earns more than those with only primary education, but not more than those with only lower secondary education. The absence of returns to upper secondary education seems counterintuitive and may be an artefact of using the clerical and semi-professional dummy in the wage equation. Ceteris paribus those in the clerical sector earn the highest premium. However, one must bear in mind that more than 75 percent of those in this category completed their secondary education and that clerical jobs are not available to most of the other wage earners as their level of education is too low.

The returns to upper secondary education may be biased downwards because models (1), (2A) and (2B) in Table 3 cannot distinguish between returns to education or returns to occupation. Recall however that from the employment status estimates (Table 2) we know that only secondary education increases the likelihood of being employed. In fact, women who completed their secondary education find employment in the government sector and consequently, earn a wage premium. However, to determine if females who are in the clerical sector earn returns to education we modify the Mincerian wage equation as follows. We interact the 10 and more years of education spline with the clerical sector dummy and include it as an explanatory variable omitting, however, the clerical sector dummy because most clerical females have at least 10 years of education. ${ }^{8}$ The estimates, presented in the last column of Table 3, indicate that clerical workers earn the highest returns to education.

To summarise, our results show that the returns to education:

(i) Equal 0 for the 0 to 7 years of education category,

(ii) Are positive for the first two years of secondary education and

(iii) Are highest for those in the clerical sector. This pattern of educational returns may arise for reasons which are consistent with our model presented in section 2.

First, firms in PMB used skill-biased technologies. Those who did not complete primary school may not qualify to occupy semi-skilled positions in PMB. The technologies were chosen to maximise white workers' wages and may have required specific training. In other words, condition (5) was met when firms chose the technology and educated blacks could not.

Second, the poor quality of education in South Africa also explains this result. During apartheid, black education was underfunded (Thomas 1996), and black students absentee rates were high since the 1976 Soweto uprising. Consequently, a primary school drop-out may not have acquired more human capital than someone who never attended school. Furthermore, most blacks are in families with few job contacts and thus may not have access to information necessary to find employment. Thus, unless educated workers work in the government sector, they earned no returns to education because of apartheid.

\section{0}

${ }^{8}$ Including both variables would lead to a near-perfect correlation. 


\section{Conclusion and Discussion}

We estimate the returns to education for black females in South Africa. We first set up a model where an apartheid government prevents blacks from working as semi-skilled workers if whites are penalised. This arises when the average level of blacks' human capital is relatively low which would force firms to use a technology where whites would earn low wages. Under such condition, blacks earn no returns to human capital investments.

Using data from the Machibisa township, to control for labour market specific factors, we find that primary education is not a predictor of employment status and secondary schools graduates are more likely to find jobs in the government sector. We also find that new migrants to Machibisa are most likely to be unemployed. Our estimates of the wage equation suggest that the returns to primary education are 0,30 per cent for the first two years of secondary education and highest for those in the government sector.

Our results have important implications in light of the skill-biased technology literature (Acemoglu 2002, Azariadis and Drazen 1990), especially if the technological choice is irreversible. If this is the case, and if black females drop out before secondary school, then one should expect the wage gap between black females and other wage earners to increase. Hence the government should implement an education policy which not only maximises school enrolment, but ensures an education of good quality, and that students complete at least primary school. As a result, it may then be possible to reduce the 50 percent current black unemployment rate (South Africa Institute of Race Relations 2002). ${ }^{9}$ Therefore, in light of our results, we can conclude that the returns to primary education in some developing countries may be overestimated when regional labour market specific factors are not accounted for.

${ }^{9}$ According to the strict (official) definition of unemployment, 36 per cent of blacks were unemployed in 2001 (South Africa Institute of Race Relations 2002). 


\section{References}

Acemoglu, Daron (1998) 'Why do new technologies complement skills? Directed technical change and wage inequality'. Quarterly Journal of Economics 113(4), 1055-1089 -(2002) 'Technical change, inequality and the labour market'. Journal of Economic Literature 40(1), 7-72

Ashenfelter, Orley C., Colm Harmon, and Hessel Oosterbeek (1999) 'A review of the schoolings/earnings relationship with tests for publication bias'. Labour Economics 6, $452-470$

Azariadis, Costas, and Allan Drazen (1990) 'Threshold externalities in economic development'. Quarterly Journal of Economics 105(2), 501-26

Behrman, Jere R., and Anil B. Deolalikar (1993) 'Unobserved household and community heterogeneity and the labour market impact of schooling: Acase study for Indonesia'. Economic Development and Cultural Change 41(3), 461-488

Bell, Trevor R., and Niki Cattaneo (1997) 'Foreign trade and employment in South African manufacturing industry'. Technical Report 5, International Labour Office, Geneva, Switzerland

Bhorat, H., M. Leibbrandt, M. Maziya, S. van der Berg, and I Woolard (2001) Fighting Poverty: Labour Markets and Inequality in South Africa (University of Cape Town Press)

Bromberger, Norman, and Francis Antonie (1993) 'Black small farmers in the homelands.' In State and Market in Post Apartheid South Africa, ed. Merle Lipton and Charles Simkins (Witwaterstrand University Press)

Butcher, Kristin F., and Cecilia Elena Rouse (2001) 'Wage effects of unions and industrial councils in South Africa'. Industrial and Labour Relations Review 54(2), 349-374

Card, David (1999) 'The causal effect of education on earnings'. In Handbook of Labour Economics, ed. David Card and Orley Ashenfelter, vol. 3 (Amsterdam: North Holland) chapter 30

Carter, Michael R., and Julian May (2001) 'One kind of freedom: Poverty dynamics in postapartheid South Africa'. World Development 29(12), 1987-2006

Cross, Catherine, Simon Bekker, and Craig Clark (1994) 'Migration into informal settlements: An overview of trends'. In Here to Stay: Informal Settlements in KwaZulu-Natal, ed. Doug Hindson and Jeff McCarthy (Dalbridge Indicator Press)

Dessy, Sylvain E., and Désiré Vencatachellum (2003) 'Explaining cross-country differences in policy response to child labour'. Canadian Journal of Economics. Forthcoming

Doeringer, Peter, and Michael A. Piore (1971) Internal Labour Markets and ManpowerAnalysis (D. C. Heath)

Friedman, M., and M. Hambridge (1991) 'The informal sector, gender and development'. In South Africa's Informal Economy, ed. E. Preston-Whyte and C. Rogerson (Oxford University Press)

Galor, Oded, and Omer Moav (2000) 'Ability biased technological transition, wage inequality and economic growth'. Quarterly Journal of Economics 115(2), 469-498 
Gerson, J. (1986) 'Unemployment in South Africa'. South African Journal of Economics 54(4), $418-429$

Hart, D. (1991) 'The informal sector in South African literature'. In South Africa's Informal Economy, ed. Preston Whyte and Rogerson (Cape Town: Oxford University Press)

Heckman, James (1979) 'Sample selection bias as a specification error'. Econometrica 47, 153-161

Heckman, James, Anne Layne-Farrar, and Petra Todd (1996) ‘Human capital pricing equations with an application to estimating the effect of schooling quality on earnings'. Review of Economics and Statistics 78(4), 562-610

Heckman, James J., Lance J. Lochner, and Petra E. Todd (2001) 'Fifty years of Mincer regressions'. Mimeo, University of Chicago

Jagannathan, N. V. (1987) Informal Markets in Developing Countries (New York: Oxford University Press)

Knight, John B., and M. D. McGrath (1977) 'An analysis of racial wage discrimination in South Africa'. Oxford Bulletin of Economics and Statistics 39(4), 245271

Liedholm, C., and D. Mead (1998) 'The dynamic role of micro and smaller enterprises in Southern Africa'. In Post-Apartheid Southern Africa: Economic Challenges and Policies for the Future, ed. Lennart Petersson (London and New York: Routledge)

Lucas, Jr. Robert E. (1988) 'On the mechanics of economic development'. Journal of Monetary Economics 22(1), 3-42

May, Julian, and S. Rankin (1990) 'The spacial and gender differentiation of KwaZulu's black labour force'. Agenda 6, 76-95

Michaud, Pierre-Carl, and Désiré Vencatachellum (2003) 'Human capital externalities in South Africa'. Economic Development and Cultural Change. Forthcoming

Moll, Peter G. (1993) 'Black South African unions: Relative wage effects in international perspective'. Industrial and Labour Relations Review 46(2), 245-261

-(1996) 'The collapse of primary schooling returns in South Africa 1960-90'. Oxford Bulletin of Economics and Statistics 58(1), 213-246

-(1998) 'Primary schooling, cognitive skills and wages in South Africa'. Economica 65(258), 263-284

Mwabu, Germano, and T. Paul Schultz (2000) 'Wage premiums for education and location of South African workers by gender and race'. Economic Development and Cultural Change 48(2), 307-334

Nattrass, Jill, and Julian Douglas May (1986) 'Migration and dependency: Sources and levels of income in Kwa Zulu'. Development Southern Africa 3(4), 583-599

Percival, Valerie, and Thomas Homer-Dixon (1995) 'Environmental scarcity and violent conflict: The case of South Africa'. Occasional Paper, American Association for the Advancement of Science and the University of Toronto

Pillay, P. (1992) 'Education, employment and earnings: A study of the South African manufacturing sector'. PhD dissertation, University of Cape Town 
Psacharopoulos, George, and Harry Anthony Patrinos (2002) 'Returns to investment in education: A further update'. Working Paper 2881, World Bank, Washington D.C., September

Rogerson, Christian M. (1996) 'Urban poverty and the informal economy in South Africa's economic heartland'. Environment and Urbanization 6(1), 167-181

Schultz, T. Paul, and Germano Mwabu (1998) 'Labor unions and the Distribution of Wages and Employment in South Africa'. Industrial and Labor Relations Review 51(4), 680-703

Simkins, Charles (1983) 'Four essays on the past, present and possible future of the distribution of the black population in South Africa'. Technical Report, SALDRU, University of Cape Town, Cape Town

Siphambe, Happy Kufigwa, and Malebogo Thokweng-Bawena (2001) 'The wage gap between men and women in Botswana's formal labour market'. Journal of African Economies 10(1), $127-142$

Soderbom, Mans, and Francis Teal (2001) 'Firm size and human capital as determinants of productivity and earnings'. Technical Report 2001-09, Centre for the Study of African Economies, Oxford University

South Africa Institute of Race Relations (2002) 'Labour trends'. Technical Report, South Africa Institute of Race Relations, http://www.sairr.org.za, June

Thomas, Duncan (1996) 'Education across generations in South Africa'. American Economic Review 86(2), 330-334

Trostel, Philip, Ian Walker, and Paul Wolley (2002) 'Estimates of the economic return to schooling for 28 countries'. Labour Economics 9(1), 1-16

Unterhalter, Elaine (1987) 'Forced removals: the division, segregation and control of the people of South Africa'. International Defence and Aid Fund

Wilson, Francis, and Mamphela Ramphele (1989) Uprooting poverty: the South African Challenge (New York and London: W. W. Norton and Co.) 


\section{Appendix A: Education Splines}

Let $s$ denote the number of years of schooling. We define the following four education splines:

$$
\begin{aligned}
& \text { Lower primary }=\min [s ; 4] \\
& \text { Upper primary }=\max [\min [s \quad 4 ; 3] ; 0]
\end{aligned}
$$

Lower secondary $=\min [\max [s \quad 7 ; 0] ; 2]$

Upper secondary and tertiary $=\max [s \quad 9 ; 0]$

Lower primary education reaches its ceiling at four years. Those who complete lower primary education can then accumulate more skills up to a maximum of seven years which constitutes the number of years of primary school. The same reasoning applies for the construction of the secondary and post-secondary variables, equations (8) and (9) respectively. 


\section{Appendix B: Tables}

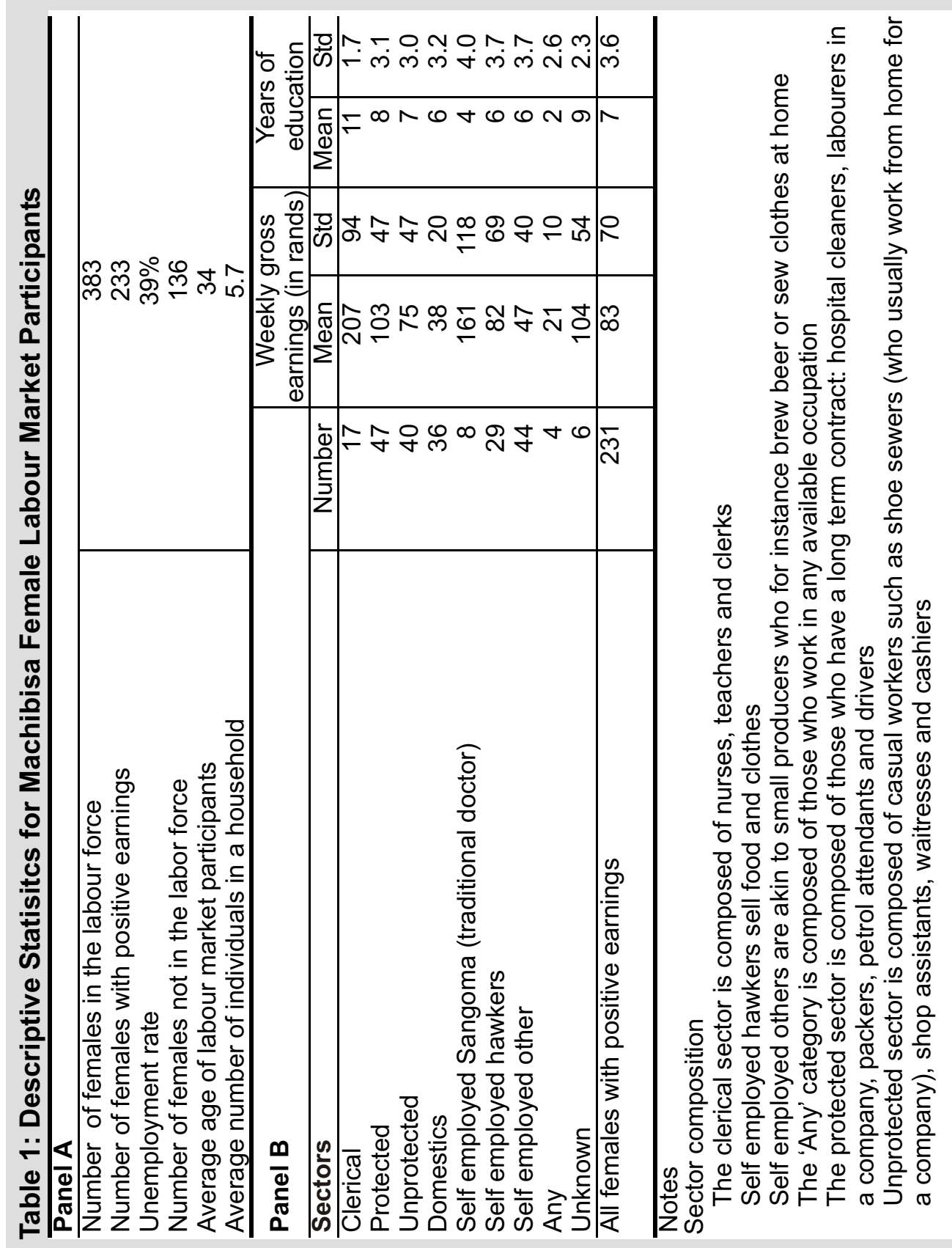


Table 2: Machibisa Females' Labour Market Participation

(a)

\begin{tabular}{l|c}
\multicolumn{1}{c|}{ Explanatory variables } & Estimate \\
\hline Constant & $-1.30^{* * *}$ \\
\hline Household head dummy & $0.58^{* * *}$ \\
Number of individuals in the household & $(3.05)$ \\
Dummy equals one if married & -0.01 \\
& $(0.53)$ \\
\hline Age & $0.27^{*}$ \\
(b) Urbanisation spline & $(1.22)$ \\
\hline Primary education spline variable & $0.02{ }^{*}$ \\
Secondary education spilne variable & $0.22{ }^{* * *}$ \\
Tertiaty education spline variable & $(3.50)$ \\
\hline Number of observations & 0.01 \\
Percentage of right predictions & $(0.28)$ \\
Log likelihood & $0.11^{*}$ \\
\hline
\end{tabular}

\section{Notes}

(a) The dependent variable equals to 1 if the labor market participant reports positive earnings in the past week, 0 otherwise. The identifying variables are Household head dummy, Number of individuals in the household, Married dummy and Urbanization spline. $A^{*},{ }^{* *}$ and ${ }^{* * *}$ indicates that the parameter is statistically different from 0 at the $10 \%, 5 \%$ and $1 \%$ respectively.

(b) The urbanisation sliple equals the number of years since the labor market participant has moved to Machibisa for those who do not exceed 4 years, it equals 4 otherwise 
Table 3: Females' Earnings Functions in Machibisa Accounting for Sample Selection Dependent variable: logarithm of weekly earnings

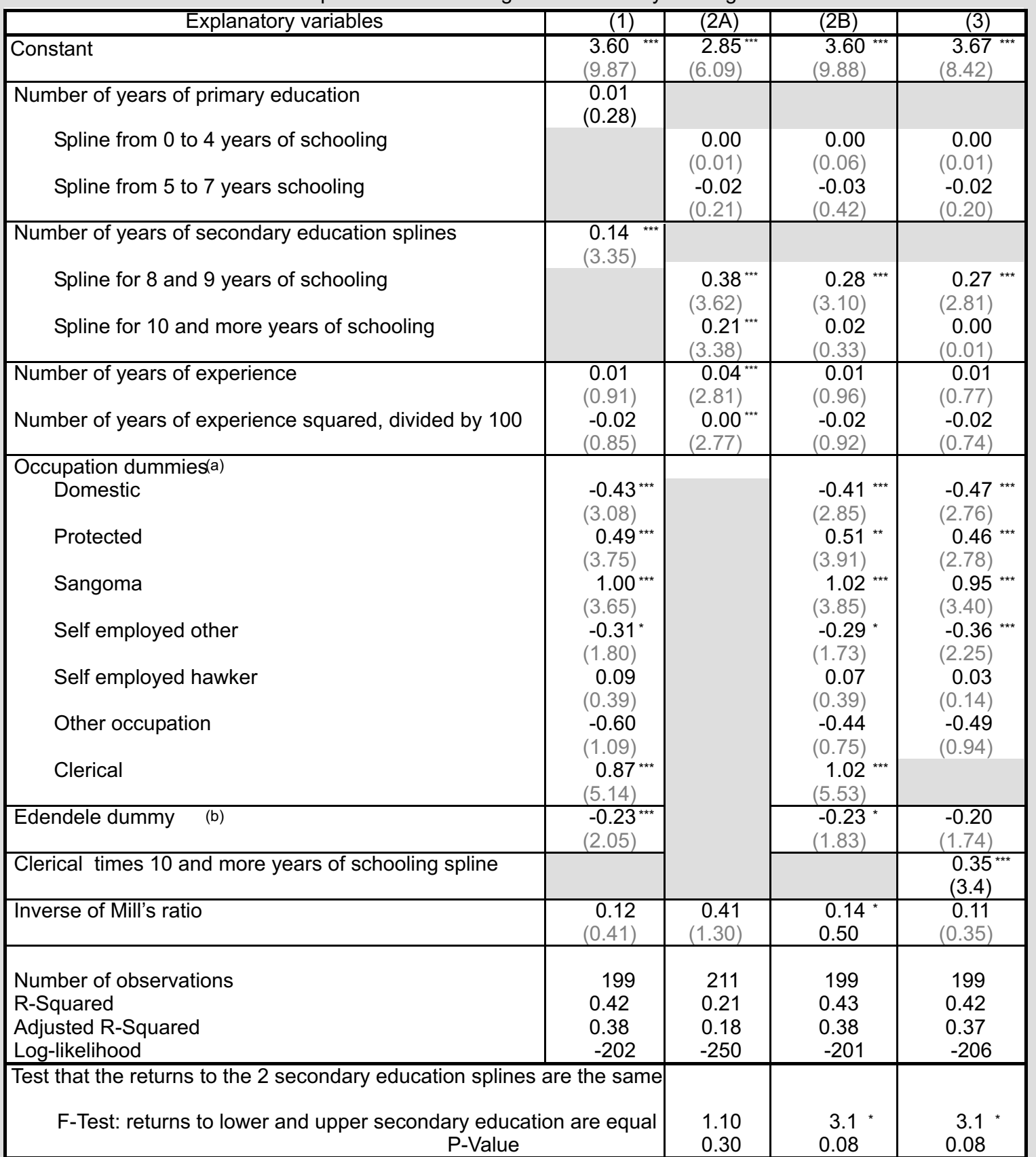

\section{Notes}

(a) The reference occupation is unprotected as defined in the note of Table 1

(b) $A^{*},{ }^{* * *}$ and ${ }^{* * *}$ denotes that the parameter is statistically different fronm 0 at the $10 \%, 5 \%$ and $1 \%$ respectively 
Table 4: OLS Estimates of Females' Earnings Functions in Machibisa

Dependent variable: logarithm of weekly earnings

\begin{tabular}{|c|c|c|c|c|}
\hline Explanatory variables & $(1)$ & $(2 \mathrm{~A})$ & $(2 \mathrm{~B})$ & $(3)$ \\
\hline Constant & $\begin{array}{l}3.58^{* * *} \\
(17.2) \\
\end{array}$ & $\begin{array}{l}3.12^{*+*} \\
(12.8)\end{array}$ & $\begin{array}{l}3.59^{*+*+} \\
(14.7)\end{array}$ & $\begin{array}{l}3.63^{* *+} \\
(14.7) \\
\end{array}$ \\
\hline Number of years of primary education & $\begin{array}{r}0.02 \\
(0.89)\end{array}$ & & & \\
\hline $\begin{array}{l}\text { Spline from } 0 \text { to } 4 \text { years of schooling } \\
\text { Spline from } 5 \text { to } 7 \text { years schooling }\end{array}$ & & $\begin{array}{r}0.02 \\
(0.42) \\
-0.02 \\
(0.24)\end{array}$ & $\begin{array}{r}0.02 \\
(0.37) \\
-0.02 \\
(0.26)\end{array}$ & $\begin{array}{r}0.02 \\
(0.32) \\
-0.01 \\
(0.07)\end{array}$ \\
\hline Number of years of secondary education splines & $\begin{array}{l}0.14^{* * *} \\
(3.74)\end{array}$ & & & \\
\hline $\begin{array}{l}\text { Spline for } 8 \text { and } 9 \text { years of schooling } \\
\text { Spline for } 10 \text { and more years of schooling }\end{array}$ & & $\begin{array}{c}0.35^{* * *} \\
(3.71) \\
0.20^{* * *} \\
(3.50) \\
\end{array}$ & $\begin{array}{c}0.28 \\
(3.16) \\
0.02 \\
(0.28) \\
\end{array}$ & $\begin{array}{c}0.28 * * \\
(3.08) \\
0.00 \\
(0.02) \\
\end{array}$ \\
\hline $\begin{array}{l}\text { Number of years of experience } \\
\text { Number of years of experience squared, divided by } 100\end{array}$ & $\begin{array}{r}0.02^{*} \\
(1.65) \\
0.00 \\
(1.28) \\
\end{array}$ & $\begin{array}{c}0.04^{* * *} \\
(3.24) \\
0.00^{* * *} \\
(3.03) \\
\end{array}$ & $\begin{array}{r}0.02 \\
(1.44) \\
0.00 \\
(1.14) \\
\end{array}$ & $\begin{array}{r}0.02 \\
(1.40) \\
0.00 \\
(1.11) \\
\end{array}$ \\
\hline Occupation dummies (a) & & & & \\
\hline Domestic & $\begin{array}{l}-0.51^{* * *} \\
(3.58)\end{array}$ & & $\begin{array}{l}-0.49^{* * *} \\
(2.93)\end{array}$ & $\begin{array}{l}-0.54^{* * *} \\
(3.27)\end{array}$ \\
\hline Protected & $\begin{array}{l}0.39^{* * *} \\
(2.88)\end{array}$ & & $\begin{array}{l}0.40^{* * *} \\
(2.63)\end{array}$ & $\begin{array}{c}0.36^{* *} \\
(2.34)\end{array}$ \\
\hline Sangoma & $0.88^{* * *}$ & & $0.89^{* * *}$ & $0.84^{* * *}$ \\
\hline Self employed other & $-0.44^{* * *}$ & & $-0.43^{* * *}$ & $-0.48^{* * *}$ \\
\hline Self employed hawker & $\begin{array}{r}0.04 \\
(0.16)\end{array}$ & & $\begin{array}{r}0.04 \\
(0.22)\end{array}$ & $\begin{array}{r}-0.02 \\
(0.09)\end{array}$ \\
\hline Other occupation & $\begin{array}{r}0.04 \\
(0.11)\end{array}$ & & $\begin{array}{r}0.10 \\
(0.29)\end{array}$ & $\begin{array}{r}0.05 \\
(0.15)\end{array}$ \\
\hline Clerical & $\begin{array}{c}0.78^{* * *} \\
(4.50) \\
\end{array}$ & & $\begin{array}{l}0.93^{* * * *} \\
(3.74) \\
\end{array}$ & \\
\hline Edendele dummy $\quad$ (b) & $\begin{array}{r}-0.20 \\
(1.93)\end{array}$ & & $\begin{array}{c}-0.21^{*} \\
(1.91)\end{array}$ & $\begin{array}{c}-0.18^{*} \\
(1.68)\end{array}$ \\
\hline Clerical times 10 and more years of schooling spline & & & & $\begin{array}{c}0.33^{* * *} \\
(3.24)\end{array}$ \\
\hline $\begin{array}{l}\text { Number of observations } \\
\text { R-Squared } \\
\text { Adjusted R-Squared } \\
\text { Log-likelihood }\end{array}$ & $\begin{array}{l}219 \\
0.41 \\
0.38 \\
-225\end{array}$ & $\begin{array}{l}233 \\
0.21 \\
0.19 \\
-277\end{array}$ & $\begin{array}{l}219 \\
0.42 \\
0.38 \\
-224\end{array}$ & $\begin{array}{l}219 \\
0.41 \\
0.37 \\
-225\end{array}$ \\
\hline
\end{tabular}

\section{Notes}

(a) The reference occupation is unprotected as defined in the note of Table 1

(b) $\mathrm{A}^{*},{ }^{* * *}$ and ${ }^{* * *}$ denotes that the parameter is statistically different fronm 0 at the $10 \%, 5 \%$ and $1 \%$ respectively 


\section{Appendix C: Location of the Area Surveyed}

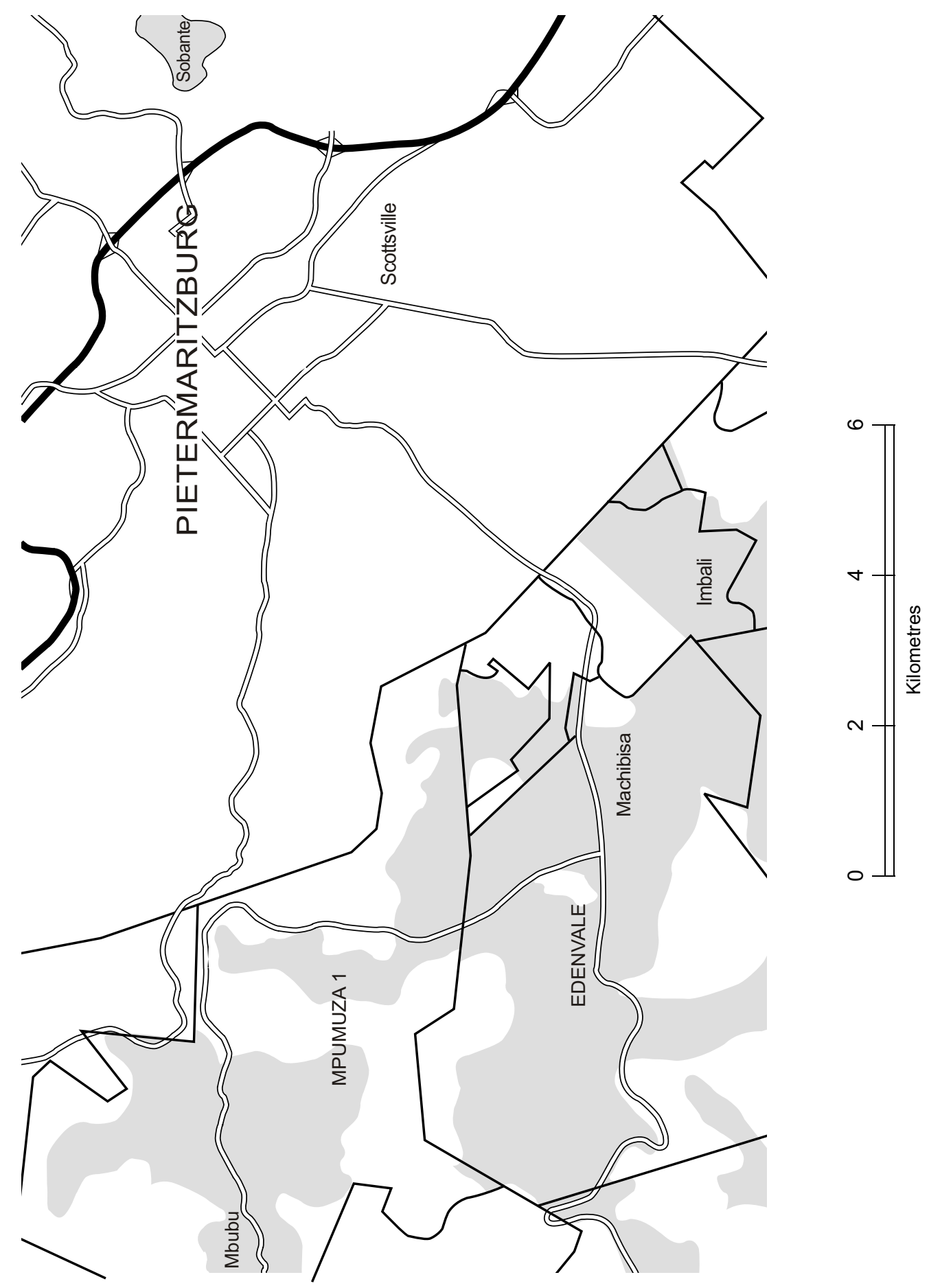

